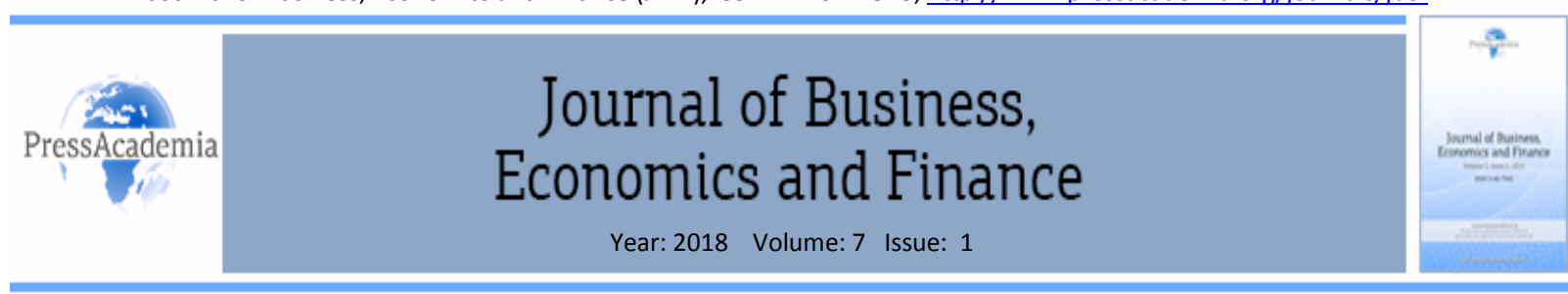

\title{
UNDERSTANDING THE DRIVERS OF GENERATION Y CONSUMERS' GREEN PURCHASE INTENTION: PRICE SENSITIVITY AS A MODERATING VARIABLE
}

\section{DOI: $10.17261 /$ Pressacademia.2018.798}

JBEF- V.7-ISS.1-2018(9)-p.89-100

\section{Melek Erdil}

Nisantasi University, Faculty of Economics, Administrative and Social Sciences, Istanbul, Turkey. melekerdil@gmail.com , ORCID: 0000-0002-2291-5602

\section{To cite this document}

Erdil, M. (2018). Understanding the drivers of generation y consumers' green purchase intention: price sensitivity as a moderating variable. Journal of Business, Economics and Finance (JBEF), V.7(1), p.89-100.

Permanent link to this document: http://doi.org/10.17261/Pressacademia.2018.798

Copyright: Published by PressAcademia and limited licensed re-use rights only.

\begin{abstract}
Purpose - The purpose of this study is to test the moderating effect of price sensitivity on the relationship between environmental knowledge, environmental concern, environmental attitude and Generation Y consumers' green purchase intention.

Methodology - A quantitative approach was used for data gathering. Data collection was conducted through online questionnaires filled out by 260 Generation Y consumers who were born between 1977 and 1994 . Multiple regression analysis and hierarchical regression analysis were applied to test the hypotheses.

Findings- The results revealed that environmental concern and environmental attitude have a significant effect on the green purchase intention of Generation $Y$ consumers. Price sensitivity of Generation $Y$ consumers moderates the relationship between environmental concern, environmental attitude and green purchase intention.

Conclusion- The results created an understanding of the factors that influence green purchase intention within the scope of consumer behavior and serve as the information for marketers to drive sales and increase market share through appropriate marketing strategies.
\end{abstract}

Keywords: Environmental attitude, environmental concern, green marketing, green purchase intentions, price sensitivity. JEL Codes: M30, M31, M39

\section{INTRODUCTION}

In recent years, preventing the environmental deterioration caused by over consumption and judicious utilization of natural resources without depleting them have been a great concern for the public. These facts have driven people to act responsible and purchase harmless goods to the environment (Elahi and Yaghoubi, 2012). Besides, both behaviors of consumers and market itself have also been changed while environmental awareness increases (Barber, Kuo, Bishop and Goodman, 2012). As environmental consciousness gains strength, the consumers started to feel themselves eager to pay extra for environmental-friendly products (Chang and Chen, 2013).

Green marketing is a management process which is supposed to provide the beneficial towards the society and customers in order to satisfy their requirements in a sustainable way (Chen and Chai, 2010). Green marketing is also termed environmental marketing which consists of producing, pricing and delivering products that are harmless or less harmful to the environment (Grant, 2008; Jain and Kaur, 2004; Kangis, 1992; Pride and Ferrell, 2008). A green consumer can be identified to be the one who avoids using products which may harm living organisms, generate environmental degradation all along manufacturing process and test on animals (Elkington and Hailes, 1994).

Since the matter of preserving environment has led consumers to think over their preference of products; many consumers are willing to pay higher prices for the items in accordance with environmental standards (Newton, Tsarenko, Ferraro and Sands, 2015). This study adopts a different perspective by focusing on Generation Y consumers' price sensitivity not on product's price itself or entire generations. The results of this research will be useful for producers of various green consumer products and marketing professionals who can use them as a source of competitive advantage in their marketing 
plans. Additionally, the researchers will be interested in the results to gain a better understanding of consumer behavior to conduct further studies.

Therefore, the objectives of this paper are to determine whether environmental knowledge, environmental attitude, environmental concern affect green purchase intention and examine the moderating effect of price sensitivity on the relationship between the independent variables (environmental knowledge, environmental concern, environmental attitude) and green purchase intention.

\section{LITERATURE REVIEW}

\subsection{Environmental Knowledge}

Conraud-Koellner and Rivas-Tovar (2009) describe environmental knowledge as the complement of ecological knowledge that people have of environmental issues. According to D'Souza, Taghian and Lamb (2006), environmental knowledge expands in two ways; firstly, consumers have to be tutored to grasp the effect of a product to environment and secondly, consumers have to be sure that the product is gone through an environmental-friendly manufacturing process.

Environmental awareness is considered as knowledge about the facts and general concepts related to the environment and ecosystems (Mostafa, 2007). This awareness is compatible with the opinion that the world's natural resources are limited and the ecological balance may be at an urgently important deterioration grade (Hayes, 1990). If the consumers are informed about the environmental problems, their awareness level will rise and so they will build positive attitudes towards green products.

Environmental knowledge is linked to positive environmental behavior (Tanner and Kast, 2003). According to Jang, Kim, and Bonn (2011), the awareness of green product consumption is essential to create an environmental ethic and it subsequently changes the consumption behavior. The more knowledge people have about green behavior practices, the more they will act positively (Roberts, 1996). Antil (1984) discovered a positive relationship between environmental knowledge and pro-environmental attitudes. However, although $40 \%$ of consumers tell that they will purchase green products, these products' market share is not big enough; because only $4 \%$ of consumers are willing pay for green products (Bartels and Hoogendam, 2011; Young, Hwang, McDonald and Oates, 2010).

\subsection{Environmental Concern}

Environmental concern is rooted in an individual's self-concept and the extent to which he or she believes to be an essential part of Mother Nature (Schultz and Zelezny, 2000). Kalafatis, Pollard, East and Tsogas (1999) define environmental concern as the consumers realize that the environment is in danger and the natural resources are finite. Environmental concern represents individuals' getting aware of environmental problems and becoming eager to be a part of the solution (Dunlap and Johns 2002).

During the last 20 years especially, there has been a dramatic rise in environmental concern that leads consumers to perceive nature's preservation as a crucial factor in making their daily purchasing decisions. Concern for environment refers to the extent to which consumers are conscious of environmental issues and supporting exertions made to fight these problems. It also includes willingness of consumers to get involved in the efforts of preventing environmental deterioration (Alibeli and Johnson, 2009) together with strong preference to buy a green product (Rashid, 2009). Former research presented that $84 \%$ of consumers stated concern on environmental issues and many consumers altered their consumptive practices (Schlossberg, 1990). In the study of Lee (2009), it was shown that environmental concern is a driver of green purchase intention of consumers and female adolescents conceive ecological issues more seriously than male adolescents. Contrarily, there are researches pointing out that while consumers state their concern towards the environment, it does not precisely result in green buying behavior (Young et al., 2010; Roberts, 1996)

\subsection{Environmental Attitude}

Attitude is a state of willingness which influences an individual to respond to various situations and objects with which it is associated (Allport, 1935). According to Amstrong and Kotler (2009), "attitude is a person's consistently favorable or unfavorable evaluations, feelings, and tendencies towards an object or idea".

Attitude characterizes consumer likes and dislikes (Blackwell, Miniard and Engel, 2006) and therefore affects purchase decisions. Attitudes are well predictors of pro-environmental behavior (Padel and Foster, 2005; Tanner and Kast, 2003). Balderjahn (1988) and Kotchen \& Reiling (2000) found that the people having a positive attitude towards the environment tend to purchase environmental-friendly products. Similarly, Florenthal and Arling (2011) revealed a significant relationship between green purchase attitudes and buying intentions. In a study conducted in Egypt, consumers' attitude towards green products influenced green purchase intentions and behavior (Mostafa, 2007). Kalafatis et al. (1999) showed that environmental attitudes led to green purchase intentions, especially in developed markets. This statement was reversed by 
Hughner, McDonagh, Prothero, Shultz and Stanton (2007) who indicated that although consumers had a favorable attitude towards green products; it did not ensure the buying of green products. In many other studies, a gap between attitude and behavior was discovered, although it was anticipated that there would be a positive relationship between environmental attitude and green purchase intention (Akehurst, Afonso and Goncalves, 2012; Laroche, Bergeron, Tomiul and BarbaroForleo, 2002; Papista and Krystallis 2012).

\subsection{Price Sensitivity}

Generally, green products are priced higher than conventional products due to higher costs borne in the process. Consumers differ in how much they are willing to pay for a given product. Price elasticity does not ascertain how individual consumers or groups of consumers respond to price (Ramirez and Goldsmith, 2009). Therefore, the notion of price sensitivity is highly beneficial to marketing managers as long as it can be measured reliably and validly (Goldsmith and Newell, 1997).

D'Souza et al. (2006) asserted that green consumers who perceived price as an insignificant element in their buying decision were eager to pay a relatively high price for green products. These findings were verified by many researches where environmentally concerned consumers stated themselves to be willing to pay extra for products with minimum harm to the environment (Laroche, Bergeron, Barbaro-Forleo, 2001; Rowlands, Scott and Parker 2003; Michaud, Llerena and Joly 2013). According to Aman, Harun and Hussein (2012), green consumers are usually less price sensitive to purchase eco-friendly goods, because they are determined to pay for safe items, and simultaneously improve animal welfare. The study carried out by Shrum, McCarty and Lowrey (1995) revealed that green consumers were price conscious and careful when shopping.

However, not all green consumers are willing to pay a higher price for green products. They are generally price sensitive as for green products and the price characteristics affect their purchasing decision (Anderson and Hansen, 2004). No matter how concerned they are, consumers can still be reluctant to pay price premiums for green products. D'Souza et al. (2006) also brings forward that purchase possibility for green products decreases as the price increases.

\subsection{Green Purchase Intention}

People are getting much aware of the environmental problems, many customers have environmental concerns and they are conscious enough to buy less destructive and environmental-friendly products (Peattie, 1995). Rashid (2009) described green purchase intention as the possibility and eagerness of consumers to give priority to green products over traditional products in their purchase decisions. It can also be described as an inner desire and willingness of consumers to purchase a less environmentally detrimental product.

Intention is a significant predictor of individuals' actual behavior in the future. Green purchase behavior is highly strung on green purchase intention; which can be explained by reasoned action and planned behavior theories (Kalafatis et al., 1999). Chan and Lau (2000) tested a model consisting of environmental concern, green purchase intention, environmental knowledge, man nature orientation and actual purchase behavior. Their results suggested that actual green purchase behavior was dependent on a person's green purchase intention. Gotschi, Vogel, Lindenthal and Larcher (2010) state that behavior is an inevitable outcome of intention, and behavioral intention results from both attitudes and subjective norms that are specified by beliefs. The green purchase intention of consumers is like a representative for their real purchase behavior (Ramayah, Lee and Mohamad, 2010). The purchase intention of the consumer positively affects the probability of a consumer's actual purchase decision to buy green products (Chen, 2013; Han, Hsu and Lee 2009).

\subsection{Conceptual Framework and Hypotheses Development}

The conceptual framework of this study strives to make a connection between Generation $Y$ consumers' environmental knowledge, environmental concern, environmental attitude and green purchase intention. Particularly for developing markets, the issue of price sensitivity is an important criterion for making a choice between green and conventional products. Since the environmental-friendly products are generally priced higher; this situation may induce unwillingness to buy them. Therefore, the framework examines the moderating effect of price sensitivity to understand the process leading to possible purchase intention. There is still much to be investigated in the field of green marketing. The studies carried out in established markets paved the way for discovering the underlying drivers of green consumption. The researches that have been mentioned above prepared the ground for developing a conceptual framework with variables related to consumers.

After reviewing the relative literature, conceptual framework and formulated hypotheses are presented in Figure 1. 
Figure 1: Conceptual Framework of the Drivers of Green Purchase Intention and the Role of Price Sensitivity as a Moderator

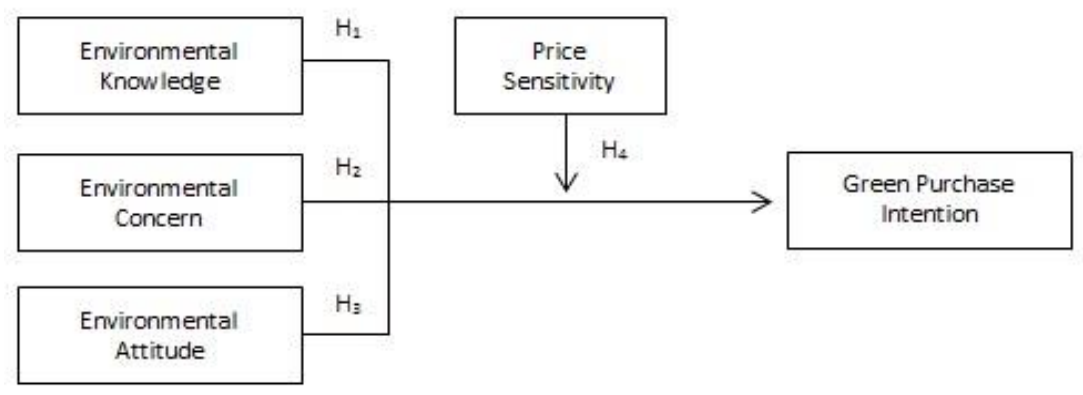

$\mathrm{H}_{1}$ : There is a significant relationship between environmental knowledge and green purchase intention.

$\mathrm{H}_{2}$ : There is a significant relationship between environmental concern and green purchase intention.

$\mathrm{H}_{3}$ : There is a significant relationship between environmental attitude and green purchase intention.

$\mathrm{H}_{4}$ : Price sensitivity moderates the relationship between environmental knowledge, environmental concern, environmental attitude and green purchase intention.

\section{DATA AND METHODOLOGY}

Convenience sampling as a type of non-probability sampling was used for the objectives of this study for the reason that convenience sampling allows researchers to gather basic information rapidly and efficiently (Sekaran, 2000).

Since, Generation $Y$ is considered to be a large group of future consumers and supposed to have greater spending power than any other consumer groups (Noble, Haytko and Phillips, 2009), the sample size of the present study consisted of Generation Y consumers born between 1977 and 1994.

A self-administered online questionnaire was distributed through e-mail based groups, forums and social media. A total of 260 completed questionnaires were obtained. Since, all the questions in the survey were compulsory to answer; no questionnaire was excluded. All the data was stored in excel spreadsheets so that it could be imported on to SPSS 22 for testing and analysis. The measurement of the survey items in this study is by means of five-point Likert scale from 1 to 5 ranging from strongly disagree to strongly agree. The questionnaire consisted of 34 questions in total and was divided into three parts. In part 1, the items about independent variables (environmental knowledge, environmental concern, and environmental attitude) were placed. In part 2, the items about moderator variable (price sensitivity) and dependent variable (green purchase intention) were presented and in part 3, respondents were asked about their socio-demographic characteristics. Table 1 represents the study variables, item numbers and sources of adapted scales.

Table 1: Scales Used in Research

\begin{tabular}{llll}
\hline No & Variable & $\begin{array}{l}\text { Number } \\
\text { of Items }\end{array}$ & Reference \\
\hline 1 & Environmental Knowledge & 8 & Mostafa (2007) \\
2 & Environmental Concern & 6 & Stern and Dietz (1994) ; Singh and Bansal (2012) \\
3 & Environmental Attitude & 5 & Akbar, Hassan, Khurshid, Niaz and Rizwan(2014) \\
4 & Price Sensitivity & 6 & Goldsmith (1996) \\
5 & Green Purchase Intention & 3 & Chen and Chang (2012) \\
\hline
\end{tabular}

\section{FINDINGS AND DISCUSSIONS}

\subsection{Sample Profile}

The majority of the respondents were male (55\%), aged between $29-34(55.4 \%)$, single (68\%), undergraduate (69.6\%), employed for wages (65\%) and have a monthly income between $2001-3000$ TRY (23.5\%). 
Table 2: Socio-Demographic Characteristics of Respondents

\begin{tabular}{|c|c|c|c|c|}
\hline No & Socio-Demographic & ariable & Frequency & Percentage \\
\hline \multirow{3}{*}{1} & \multirow{3}{*}{ Gender } & Female & 117 & 45 \\
\hline & & \multirow[t]{2}{*}{ Male } & 143 & 55 \\
\hline & & & 260 & 100 \\
\hline \multirow{4}{*}{2} & \multirow{4}{*}{ Age } & $23-28$ & 76 & 29.2 \\
\hline & & $29-34$ & 144 & 55.4 \\
\hline & & $35-40$ & 40 & 15.4 \\
\hline & & & 260 & 100 \\
\hline \multirow{3}{*}{3} & \multirow{3}{*}{ Marital Status } & Single & 177 & 68 \\
\hline & & Married & 83 & 32 \\
\hline & & & 260 & 100 \\
\hline \multirow{6}{*}{4} & \multirow{6}{*}{ Education Level } & Less than high school graduate & 3 & 1.1 \\
\hline & & High school graduate & 12 & 4.6 \\
\hline & & Undergraduate & 181 & 69.6 \\
\hline & & Graduate & 46 & 17.7 \\
\hline & & Post-graduate & 18 & 7 \\
\hline & & & 260 & 100 \\
\hline \multirow{4}{*}{5} & \multirow{5}{*}{ Employment Status } & Employed for wages & 169 & 65 \\
\hline & & Self-employed & 28 & 10.7 \\
\hline & & Out of work & 27 & 10.3 \\
\hline & & Student & 36 & 14 \\
\hline \multirow{8}{*}{6} & & & 260 & 100 \\
\hline & \multirow{7}{*}{ Monthly Income } & 1000 TRY or less & 52 & 20 \\
\hline & & 1001-2000 TRY & 40 & 15.3 \\
\hline & & 2001-3000 TRY & 61 & 23.5 \\
\hline & & 3001-4000 TRY & 48 & 18.5 \\
\hline & & 4001-5000 TRY & 37 & 14.2 \\
\hline & & 5001 TRY and above & 22 & 8.5 \\
\hline & & & 260 & 100 \\
\hline
\end{tabular}

\subsection{Descriptive Analysis}

As shown in Table 3, the means of all variables are above the average level ( 3 out of 5). This indicates that Generation $Y$ consumers have high levels of environmental knowledge, environmental concern and environmental attitude. The highest mean (4.35 out of 5 ) and the lowest standard deviation (0.51) are related to the variable of price sensitivity; the lowest mean ( 2.98 out of 5 ) and the highest standard deviation ( 0.62 ) are related to the variable of green purchase intention.

Table 3: Descriptive Statistics

\begin{tabular}{clccc}
\hline No & Variable & $\begin{array}{c}\text { Number of } \\
\text { Items }\end{array}$ & Mean & $\begin{array}{c}\text { Standard } \\
\text { Deviation }\end{array}$ \\
\hline 1 & Environmental Knowledge & 8 & 3.65 & 0.53 \\
2 & Environmental Concern & 6 & 3.59 & 0.54 \\
3 & Environmental Attitude & 5 & 3.63 & 0.56 \\
4 & Price Sensitivity & 6 & 4.35 & 0.51 \\
5 & Green Purchase Intention & 3 & 2.98 & 0.62 \\
\hline
\end{tabular}




\subsection{Factor Analysis}

The results of factor analysis reveal that the variables shown in Table 4 are adequate for minimum required value of KaiserMeyer-Olkin (0.6) and value of Bartlett's Test of Sphericity (sig. at 0.005) (Kaiser, 1970). For that matter, the sample size is widely accepted and there are enough correlations among variables.

Table 4: Results of Factor Analysis

\begin{tabular}{clcc}
\hline No & Variable & KMO Value & $\begin{array}{c}\text { Bartless's Test of Sphericity, } \\
\text { significant }\end{array}$ \\
\hline 1 & Environmental Knowledge & 0.769 & 0.000 \\
2 & Environmental Concern & 0.738 & 0.000 \\
3 & Environmental Attitude & 0.743 & 0.000 \\
4 & Price Sensitivity & 0.825 & 0.000 \\
5 & Green Purchase Intention & 0.811 & 0.000 \\
\hline
\end{tabular}

\subsection{Reliability Analysis}

According to Sekaran and Bougie (2010), Cronbachs's Alpha value; less than 0.60 is poor, between 0.60 and 0.80 is acceptable, and above 0.80 is good for reliability. As seen in Table 5, Chronbach's Alpha values calculated for research variables in Table 5 are above 0.8 and this indicates that the survey instrument is highly reliable to measure five variables.

Table 5: Reliability of Research Variables

\begin{tabular}{llcc}
\hline No & Variable & $\begin{array}{c}\text { Number of } \\
\text { Items }\end{array}$ & $\begin{array}{c}\text { Cronbach's } \\
\text { Alpha }\end{array}$ \\
\hline 1 & Environmental Knowledge & 8 & 0.843 \\
2 & Environmental Concern & 6 & 0.852 \\
3 & Environmental Attitude & 5 & 0.803 \\
4 & Price Sensitivity & 6 & 0.888 \\
5 & Green Purchase Intention & 3 & 0.879 \\
\hline
\end{tabular}

\subsection{Multiple Regression Analysis}

According to multiple regression analysis results shown in Table 6 , the variables of environmental concern and environmental attitude explain $72 \%\left(R^{2}=0.72\right)$ of green purchase intention with the significance level of $0.000(p=0.000)$. As seen in Table 7, the standardized beta coefficients for environmental concern and environmental attitude are 0.506 and 0.488 respectively, with the significant level of $0.000(p<0.05)$. This reveals that environmental concern and environmental attitude have significant influence on the green purchase intention of Generation $Y$ consumers. On the other hand, the standardized beta coefficient for environmental knowledge is 0.092 , with the significance level of $0.321(p<0.05)$. The results indicate that, environmental knowledge has no significant influence on the green purchase decision of Generation $Y$ consumers. In another saying, it is possible to predict green purchase intention with environmental concern and environmental attitude of consumers but not with environmental knowledge. Based on these results, while $\mathrm{H}_{1}$ is rejected, both $\mathrm{H}_{2}$ and $\mathrm{H}_{3}$ are accepted.

Table 6: Model Summary of Green Purchase Intention

\begin{tabular}{cccccc}
\hline Model & R & R Square & Adjusted R Square & F & Sig (F) \\
\hline 1 & 0.865 & 0.721 & 0.718 & 33.891 & 0.000 \\
\hline
\end{tabular}

Predictors: (Constant): Independent variables (Environmental Knowledge, Environmental Concern, Environmental Attitude)

Dependent Variable: Green Purchase Intention 
Table 7: Regression between Environmental Knowledge, Environmental Concern, Environmental Attitude and Green Purchase Intention

\begin{tabular}{lccc}
\hline Variables & Std. Beta & t value & Sig. \\
\hline Environmental Knowledge & 0.092 & 1.966 & 0.321 \\
Environmental Concern & 0.506 & 5.609 & 0.003 \\
Environmental Attitude & 0.488 & 4.651 & 0.002 \\
\hline
\end{tabular}

\subsection{Hierarchical Regression Analysis}

Table 8 demonstrated the results of three-step hierarchical regression analysis of price sensitivity as the moderating variable affecting the relationship between independent variables (environmental knowledge, environmental concern and environmental attitude) and dependent variable (green purchase intention).

Hierarchical regression is a framework for model comparison. According to the research questions, several regression models are built by adding variables to a previous model at each step meanwhile including smaller models in previous steps. The aim is to test whether newly added variable would cause a significant increase in $R^{2}$.

In this study, Model 1, with environmental knowledge, environmental concern and environmental attitude as predictors of green purchase intention indicated an $\mathrm{R}^{2}$ value of 0.641 accounting for $64 \%$ of the variance, which was showing a significantly positive relationship $\left(\mathrm{F}_{(3.174)}=22.861, \mathrm{p}<0.05\right)$ between predictor variables and dependent variable.

Next, Model 2, including one moderator variable (price sensitivity), gave a better value with an $\mathrm{R}^{2}$ of 0.622 , explaining $62 \%$ of variance. The change in $R^{2}$ was significant $F_{(1.156)}=20.989, p<0.05$, thus price sensitivity proved to be a predictor of green purchase behavior and accounted above the variability contributed by the previous predictor variables in Model 1 . This result served the aim of applying hierarchical regression analysis in this study.

In order to confirm price sensitivity making a moderation effect on the relationship between dependent and independent variable, it must be shown that the nature of this relationship changes as the values of the moderating variable change. This can be proven by including interaction effect in Model 3 to check whether such an interaction is statistically significant and a significant $R^{2}$ change has occurred as a result of this test or not. If both results prove to be significant, it is determined that moderation has occurred.

The third and final model of this study comprised of interaction between independent variables and moderator variable. It gave an $R^{2}$ of 0.607 , meaning $60.7 \%$ of the variance was explained. The $R^{2}$ change was found significant $F_{(3.253)}=18.347$, $\mathrm{p}<0.05$.

The results indicate that price sensitivity significantly moderates independent variables on green purchase intention, but for the interaction between environmental knowledge and price sensitivity is not significant with 0.642 ( $p>0.05)$. The negative correlation was displayed between these variables and dependent variable, showing that when environmental knowledge and price sensitivity acted together, a decrease in the willingness to buy green products was expected to happen. However, since the interaction was found to be insignificant, it can be said that it is not possible to predict green purchase intention by the interaction of environmental knowledge and price sensitivity.

On the other hand, the interaction of environmental concern and price sensitivity was found statistically significant with 0.001 ( $p<0.01)$. The negative correlation between these variables and dependent variable assert that when Generation $Y$ consumers' environmental concern and price sensitivity tend to be high together, this situation will inevitably lead to a decrease in green purchase intention. The prediction of this decrease proved to be significantly possible as a result of applied analysis.

Similar to these results, the interaction between environmental attitude and price sensitivity was found statistically significant with $0.001(p<0.01)$. Once again, as a negative correlation suggests, Generation $Y$ consumers' higher environmental attitude and price sensitivity will result in a diminishing of their eagerness to buy green products. It is possible to predict this decrease effect by relying on the results of hierarchical regression analysis. Consequently, $\mathrm{H}_{4}$ is partially accepted.

The terms of environmental knowledge, environmental concern and environmental attitude sound positive and they are expected to affect green purchase intention positively as can be seen in Model 1. However, predicting green purchase intention by only these variables would not be sufficient to handle the issue comprehensively. Particularly, in emerging 
economies where environmental issues are raised gradually and the reaction of consumers vary enormously, other possible criteria related to purchase decisions must be calculated. One of the most important factors which could affect green buying behavior is price itself. The remarkable side of the negative correlations in this study lies in the meaning of the term 'price sensitivity'. It means that the Generation $Y$ consumers whose price sensitivity is above average tend to choose notbuying relatively high priced green products independently of their environmental concern and environmental attitude. So, when it is scored high, it eventually hinders the involvement of consumers in green purchase intention.

Table 8 demonstrated the results of hierarchical regression analysis of price sensitivity as the moderating variable affecting the relationship between independent variables (environmental knowledge, environmental concern and environmental attitude) and green purchase intention. The $F$ change is stated as significant with $0.001(p<0.05)$ in all models. The $R^{2}$ of the model is 0.60 which explaining $60 \%$ of the total variance in the model. The results indicate that price sensitivity significantly moderates independent variables on green purchase intention, but for the interaction between environmental knowledge and price sensitivity is not significant with 0.642 ( $p>0.05)$. On the other hand, both environmental concern and environmental attitude were discovered as significant predictors of green purchase intention with $0.001(p<0.01)$. The interaction between environmental concern and price sensitivity was found statistically significant with $0.001(p<0.01)$ similar to the interaction between environmental attitude and price sensitivity with $0.001(p<0.01)$. So, $H_{4}$ is partially accepted.

In addition, these interactions were found in negative correlation with dependent variable, green purchase intention. These results reveal that the interaction of environmental concern and price sensitivity will reduce the green purchase intention of Generation $Y$ consumers. Likewise, the interaction between environmental attitude and price sensitivity will diminish the green purchase intention. While price sensitivity increases, the green purchase intention decreases. In short, although participants' environmental concern and environmental attitude levels are above average, price sensitivity hinders their involvement in green purchase intention.

Table 8: Hierarchical Regression Results Using Price Sensitivity as Moderator in the Relationship between Environmental Knowledge, Environmental Concern, Environmental Attitude and Green Purchase Intention

\begin{tabular}{|c|c|c|c|c|c|c|}
\hline \multirow{2}{*}{ Independent Variables } & \multicolumn{2}{|c|}{ Model 1} & \multicolumn{2}{|c|}{ Model 2} & \multicolumn{2}{|c|}{ Model 3} \\
\hline & Std B & Sig & Std B & Sig & Std B & Sig \\
\hline \multicolumn{7}{|l|}{ Model Variables } \\
\hline Environmental Knowledge & 0.092 & 0.321 & 0.090 & 0.146 & -0.089 & 0.476 \\
\hline Environmental Concern & 0.506 & 0.003 & 0.509 & 0.002 & 0.499 & $0.001 * *$ \\
\hline Environmental Attitude & 0.488 & 0.002 & 0.544 & 0.002 & 0.586 & $0.001 * *$ \\
\hline \multicolumn{7}{|l|}{ Moderating Variable } \\
\hline Price Sensitivity & & & 0.072 & 0.003 & 0.127 & $0.003 *$ \\
\hline \multicolumn{7}{|l|}{ Interaction Terms } \\
\hline Environmental Knowledge*Price Sensitivity & & & & & -0.053 & 0.642 \\
\hline Environmental Concern*Price Sensitivity & & & & & -0.670 & $0.001 * *$ \\
\hline Environmental Attitude*Price Sensitivity & & & & & -0.713 & $0.001 * *$ \\
\hline $\mathbf{R}^{2}$ & 0.641 & & 0.622 & & 0.607 & \\
\hline $\mathrm{R}^{2}$ Change & 0.575 & & 0.585 & & 0.528 & \\
\hline $\mathbf{F}$ & 22.861 & & 20.989 & & 18.347 & \\
\hline Sig. F Change & 0.001 & & 0.001 & & 0.001 & \\
\hline
\end{tabular}

Note: Significant at $* * p<0.01 ;{ }^{*} p<0.05$

Dependent Variable: Green Purchase Intention

These results highlighted that there is a significant relationship between environmental concern, environmental attitude and green purchase intention of Generation $Y$ consumers with moderating effect of price sensitivity.

Environmental knowledge is said to be a good predictor of green purchase intention of consumers (Makesh and Ganapathi, 2012). Kim and Cheung (2011) and Wu and Teng (2011) assert that knowing the environmental issues produces a significant effect on green purchase intention. However, the findings in this study does not support these results and many other 
researches (Chen and Chang, 2012; Rizwan, Ahmad and Mehboob, 2013; Tan, 2013). According the observed results, environmental knowledge has insignificant relationship with the purchase intention of Generation Y consumers. This can be attributed to the fact that participants' level of environmental knowledge is not high enough to result in green purchase intention or the phenomenon has not taken seriously yet.

Newton et al. (2015) searched the effects of environmental concern on green purchase intention. The results showed that environmental concern affected the intention to purchase directly as many other researchers proved so (Biswas and Mousumi, 2015; Bertrandias and Gambier, 2014; Brécard, Hlaimi, Lucas, Perraudeau and Salladarré, 2009). The findings of this study support these previous researches by revealing a significant relationship between environmental concern and green purchase intention.

Cleveland, Kalamas and Laroche (2005) found that environmental attitude is a factor influencing environmental-friendly purchasing behavior. Hartmann and Apaolaza-lbáñez (2012) conducted a research and stated the impact of psychological interests and environmental concerns on consumers' attitudes and intention of buying green products. The findings of this study are in compliance with former studies by revealing a significant relationship between environmental attitude and green purchase intention.

High price can impede actual purchase where consumers are price sensitive. As might be expected, people's level of environmental concern has a connection with their interest and willingness to purchase green products (Kim and Choi, 2005; Cornelissen, Pandelaere, Warlop and Dewitte, 2008). In Biswas and Mousumi (2015)'s study, it was presented that price sensitivity was a priority in consumers' product choice. Supporting their findings, the results of this study reveal that price sensitivity has a moderating role on the relationship between environmental concern, environmental attitude and green purchase behavior. It can be inferred that, high price is still a determinant for participants whether to make a final decision of buying a green product regardless of their high level of environmental concern and environmental attitude.

\section{CONCLUSION}

In this study, two out of four hypotheses have been accepted, it can be concluded that environmental concern and environmental attitude play an important role in affecting Generation $Y$ consumers' purchase decision of green products. One of the hypotheses asserting that it is possible to predict green purchase behavior by environmental knowledge variable is rejected. It is revealed that although mean of Generation $Y$ consumers' environmental knowledge is not low, it may not result in purchase intention. The last hypothesis suggesting that price sensitivity moderates the relationship environmental concern, environmental attitude and green purchase intention is partially accepted because it does not have a moderating effect with environmental knowledge variable. Participants show great sensitivity towards relatively high prices of green products and they are not willing enough to pay extra even though their environmental concern and environmental attitude are positive.

Theoretically, this study contributes to the literature of consumer behavior by exploring predictors and motivators of green purchase intention of Generation $Y$ consumers. Practically, it provides insights into buying intention patterns of consumers for marketers to help them formulate strategies to boost green product sales. Specifically, these strategies should be made to benefit from environmental attitude to overcome price sensitivity in order to drive sales. Running promotional campaigns for green products can be an effective tool which might help to encourage the purchase intention of price sensitive consumers.

As with any research, there were a number of limitations in this study. The research findings cannot be generalized to the entire Turkish Generation Y consumers, since only 260 people were reached. For this study, only four variables related to consumers have been investigated, it can be improved by variables concerning products and brands. This study did not target a specific product, which might also have influenced the findings. Several other external and also internal factors can be tested for various product categories in further studies. Generation $Y$ consumers in other countries can be included to broaden the scope of the study by referring cultural differences and buying patterns.

\section{REFERENCES}

Akbar, W., Hassan, S., Khurshid, S., Niaz, M. and Rizwan, M. (2014). Antecedents Affecting Customer's Purchase Intentions towards Green Products, Journal of Sociological Research, 5(1), 273-289.

Akehurst, G., Afonso, C. and Goncalves, H. (2012). Re-examining green purchase behaviour and the green consumer profile: new evidences. Management Decision, 50(5), 972-988.

Alibeli, M., and Johnson, C. (2009). Environmental Concern: A Cross National Analysis. Journal of International and cross-cultural studies, 3(1), 1-10.

Allport, G.W. (1935). Attitudes. In a Handbook of Social Psychology. Worcester, MA: Clark University Press. 
Aman, A. H. L., Harun, A., \& Hussein, Z. (2012). The influence of environmental knowledge and concern on green purchase intention the role of attitude as a mediating variable. British Journal of Art and Social Sciences, 7(2), 145-167.

Anderson, R.C. and Hansen, E.N. (2004). The impact of environmental certification on preferences for wood furniture: A conjoint analysis approach. Forest Product Journal, 54(3), 42-50.

Antil, J.H. (1984). Socially responsible consumers: Profile and implications for public policy. Journal of Macromarketing, 4(2), 18-39.

Armstrong, G., and Kotler, P. (2009). Marketing: An Introduction. Ninth Edition. United States of America: Pearson Prentice Hall.

Balderjahn, I. (1988). Personality variables and environmental attitudes as predictors of ecologically responsible consumption patterns. Journal of Business Research, 17(1), 51-56.

Barber, N., Kuo, P. F., Bishop, M., and Goodman, R. (2012). Measuring psychographics to assess purchase intention and willingness to pay. Journal of Consumer Marketing, 29(4), 280-292.

Bartels, J. and Hoogendam, K. (2011). The role of social identity and attitudes toward sustainability brands in buying behaviours for organic products. Journal of Brand Management, 18(9), 697-708.

Bertrandias, L. and Gambier, L. (2014). Others' environmental concern as a social determinant of green buying. Journal of Consumer Marketing, 31(6), 417-429.

Biswas, A. and Mousumi, R. (2015). Green products: an exploratory study on the consumer behaviour in emerging economies of the East. Journal of Cleaner Production, 87(1), 463-468.

Blackwell, R. D., Miniard, P. W. and Engel, J. F. (2006). Consumer Behavior. Tenth edition. United States of America: Southwestern College.

Brécard, D., Hlaimi, B., Lucas, S., Perraudeau, Y. and Salladarré, F. (2009). Determinants of demand for green products: An application to eco-label demand for fish in Europe. Ecological Economics, 69(1), 115-125.

Chan, R. Y. and Lau, L. B. (2000). Antecedents of green purchases: A survey in China. Journal of Consumer Marketing, 17(4), 338-357.

Chang, C. H. and Chen, Y. S. (2013). Managing green brand equity: The perspective of perceived risk theory. Qual Quant, 1-16.

Chen, L. Y. (2013). A Study of Green Purchase Intention Comparing with Collectivistic (Chinese) and Individualistic (American) Consumers in Shanghai, China. Information Management and Business Review, 5(7), 342-346.

Chen, T.B. and L.T. Chai (2010). Attitude towards the environment and green products: Consumers perspective. Management Science and Engineering. 4(2), 27-39.

Chen, Y. S., and Chang, C. H. (2012). Enhance green purchase intentions: The roles of green perceived value, green perceived risk, and green trust. Management Decision, 50(3), 502-520.

Cleveland, M., Kalamas, M. and Laroche, M. (2005). Shades of green: linking environmental locus of control and pro-environmental behaviors. Journal of Consumer Marketing, 22(4), 198-212.

Conraud-Koellner, E., and Rivas-Tovar, L. A. (2009). Study of Green Behavior with a Focus on Mexican Individuals. iBusiness, 1(2), $124-131$.

Cornelissen, G., Pandelaere, M., Warlop, L. and Dewitte, S. (2008). Positive cueing: Promoting sustainable consumer behaviour by cueing common environmental behaviours as environmental. International Journal of Research in Marketing, 25, 46-54.

D'Souza , C . , Taghian , M . , Lamb , P .and Peretiatkos , R. (2006). Green products and corporate strategy: An empirical investigation. Society and Business Review,1(2), 144-157.

Dunlap, R. E. and Jones, R. E. (2002). Environmental concern: conceptual and measurement issues. In: Handbook of Environmental Sociology, R.E.Dunlap \& W.Michelson (Eds.), pp.482-524, Westport, CT: Greenwood Press.

Elahi, S. and Yaghubi, R. (2012). The introduction of green marketing tools and their impact on consumer purchasing behavior. Improvement and transformation management studies, 21(5), 167-168.

Elkington J. and Hailes J. (1994). The Green Consumer. First Edition. United Kingdom: Penguin Books.

Florenthal, B. and Arling, P. A. (2011). Do green lifestyle consumers appreciate low involvement green products, Marketing Management Journal, 21(2), 35-45.

Goldsmith, R. E. (1996). Service innovativeness and price sensitivity: An exploratory study. Association of Marketing Theory and Practice Proceedings, 5, 85-91.

Goldsmith, R. E., and Newell, S. J. (1997). Innovativeness and price sensitivity: Managerial, theoretical, and methodological issues. Journal of Product and Brand Management, 6(3), 163-174.

Gotschi, E., Vogel, S., Lindenthal, T., and Larcher, M. (2010). The Role Of Knowledge, Social Norms, And Attitudes Toward Organic Products And Shopping Behavior: Survey Results From High School Students in Vienna. The Journal of Environmental Education, 41(2), 88-100.

Grant, J. (2008). Viewpoint Green Marketing. Strategic Direction, 24(6), 25-27. 
Han, H., Hsu, L. T., and Lee, J. S. (2009). Empirical Investigation Of The Roles Of Attitudes Towards Green Behaviors, Overall Image, Gender, And Age In Hotel Customers' Eco-friendly Decision-making Process. International Journal of Hospitality Management, 28, 519-528.

Hartmann, P. and Apaolaza-Ibáñez, V. (2012). Consumer attitude and purchase intention toward green energy brands: The roles of psychological benefits and environmental concern. Journal of Business Research, 65(9), 1254-1263.

Hayes, D. (1990). The green decade. The Amicus Journal, 12, 24-29.

Hughner R. S., Mc Donagh P., Prothero A., Shultz C.J. and Stanton J. (2007). Who are organic food consumers? A compilation and review of why people purchase organic food. Journal of Consumer Behaviour, 6(2-3), 94-110.

Jain, S. K., and Kaur, G. (2004). Green marketing: An Indian perspective. Decision, 31(2), 18-31.

Jang, Y. J., Kim, W. G. and Bonn, M. A. (2011). Generation Y consumers' selection attributes and behavioral intentions concerning green restaurants. International Journal of Hospitality Management, 30(4), 803-811.

Kaiser, H. F. (1970). A Second-Generation Little Jiffy. Psychometrika, 35(4), 401-415.

Kalafatis, S. P., Pollard, M., East, R., and Tsogas, M. H. (1999). Green marketing and Ajzen's Theory of Planned Behaviour: A cross-market examination. Journal of ConsumerMarketing, 16(5), 441-460.

Kangis, P. (1992), Concerns about Green Marketing. International Journal of Wine Marketing, 4(2), 21-24.

Kim, H. Y. and Chung J. E. (2011). Consumer Purchase Intention for Organic Personal Care Products. Journal of Consumer Marketing, 28(1), 40-47.

Kim, Y. and Choi, S. R. (2005). Antecedents of green purchase behaviour: An examination of collectivism, environmental concern and PCE. Advances in Consumer Research, 32(1), 592-599.

Kotchen, and Reiling, S. (2000). Environmental attitudes, motivations, and contingent valuation of nonuse values: A case study involving endangered species. Ecological Economics, vol. 32, 93-107.

Laroche, M., Bergeron, J. and Barbaro-Forleo, G. (2001). Targeting consumers who are willing to pay more for environmentally friendly products. Journal of Consumer Marketing, 18(6), 503- 520.

Laroche, M., Bergeron, J., Tomiul, M., and Barbaro-Forleo, G. (2002). Cultural differences in environmental knowledge, attitudes and behaviours of Canadian consumers, Canadian Journal of Administrative Sciences, 19(3), 267-283.

Lee, K. (2009). Gender differences in Hong Kong adolescent consumers' green purchasing behavior. Journal of Consumer Marketing, 26(2), 87-96.

Mahesh, N. and Ganapathi, R. (2012). Influence of Consumer's Socio-Economic Characteristics and Attitude on Purchase Intention of Green Products. International Journal of Business and Management, 4(5), 33-37.

Michaud, C., Llerena, D., Joly, I. (2013). Willingness to pay for environmental attributes of non-food agricultural products: a real choice experiment. European Review of Agricultural Economics, 40(2), 313-329.

Mostafa, M. M. (2007). Gender differences in Egyptian consumers' green purchase behaviour: the effects of environmental knowledge, concern and attitude. International Journal of Consumer Studies, 31(3), 220-229.

Newton, J., Tsarenko, Y., Ferraro, C. and Sands, S. (2015). Environmental concern and environmental purchase intentions: The mediating role of learning strategy. Journal of Business Research, 68(9), 1974-1981.

Noble, S. M., Haytko, D. L. and Phillips, J. (2009). What drives college-age Generation Y consumers?. Journal of Business Research, 62(6), 617-628.

Padel, S. and Foster, C. (2005). Exploring the gap between attitudes and behaviour: Understanding why consumers buy or do not buy organic food. British Food Journal, 107(8): 606-625.

Papista, E. and Krystallis, A. (2012). Investigating the types of value and cost of green brands: Proposition of a conceptual framework. Journal of Business Ethics, 115(1), 93-100.

Peattie, K. (1995). Environmental Marketing Management: Meeting the Green Challenge. London: Pitman Publishing.

Pride, W. M., and Ferrell, O. C. (2008). Marketing. Fourteenth edition. New York: Houghton Mifflin.

Ramayah, T., Chow Lee, J. and Mohamad, O. (2010). Green product purchase intention: Some insights from a developing country. Resources, Conservation and Recycling, 54(12), 1419-1427.

Ramirez, E., and Goldsmith R. E. (2009). Some Antecedents of Price Sensitivity. Journal of Marketing Theory and Practice, 17(3), 199-213.

Rashid, N. R. (2009). Awareness of Eco-label in Malaysia's Green Marketing Initiative. International Journal of Business and Management, $4(8), 132-141$.

Rizwan, M., Ahmad, S. U. and Mehboob, N. (2013). Enhancing the Green Purchase Intention Based on Green Marketing: An Empirical Study from Pakistan. Asian Journal of Empirical Research, 3(2), 208-219. 
Roberts, J. A. (1996). Green consumers in the 1990s: profile and implications for advertising. Journal of Business Research, 36(3), $217-231$.

Rowlands, I. H., Scott, D. and Parker, P. (2003). Consumers and green electricity: profiling potential purchasers. Business Strategy and the Environment, 12(1), 36-48.

Schlossberg, H. (1990). Environmental concerns lead some consumers to change buying habits. Marketing News, $24,7$.

Schultz, P.W. and Zelezny, L.C. (2000). Promoting environmentalism. The Journal of Social Issues, 56(3), $443-457$.

Sekaran, U. (2000). Research Business Methods: A Skill Building Approach. Third Edition. United States of America: John Wiley and Sons Inc.

Sekaran, U., and Bougie, R. (2010). Research Method for Business: A Skill Building Approach. Fifth Edition. United Kingdom: John Willey and Sons Inc.

Shrum, L. J., Mc Carty, J. A. and Lowrey, T. M. (1995). Buyer characteristics of the green consumer and their implication for advertising strategy. Journal of Advertising, 24(2), 71-90.

Singh, A. and Bansal, M. (2012). Green marketing: A study of consumer attitude and environment concern. The Indian Journal of Commerce, 65(2), 273-283.

Stern, P. C. and Dietz, T. (1994). The value basis of environmental concern. Journal of Social Issues, 50(3), 65-84.

Tan, T. H. (2013). Use of Structural Equation Modeling to Predict the Intention to Purchase Green and Sustainable Homes in Malaysia. Asian Social Science, 9(10). 181-191.

Tanner, C. and Kast, S. W. (2003). Promoting Sustainable Consumption: Determinants of Green Purchases by Swiss Consumers. Psychology \& Marketing, 20(10), 883-902.

Young, W., Hwang, K., McDonald, S. and Oates, C. J. (2010). Sustainable Consumption: Green Consumer Behaviour when Purchasing Products. Sustainable Development, 18(1), 20-31.

Wu, K., and Teng, Y. (2011). Applying the Extended Theory of Planned Behaviour to Predict the Intention of Visiting a Green Hotel. African Journal of Business Management, 5(17), 75579-75587. 